\title{
Agrogeofisika Metode Self Potential Guna Evaluasi Lahan Perkebunan Tebu
}

\author{
Puguh Hiskiawan \\ Jurusan Fisika, FMIPA, Universitas Jember \\ Email :Puguh_h.fmipa@unej.ac.id
}

\begin{abstract}
ABSTRAK
Agrigeofisika adalah cabang geofisika yang berhubungan dengan ilmu pertanian . Geofisika adalah ilmu yang mempelajari penerapan prinsip-prinsip fisika untuk mempelajari bawah permukaan bumi , baik dalam dangkal skala ( dari kerak ke mantel) atau skala (hingga inti bumi ). Potensi diri adalah potensial listrik alami yang ada di bumi yang timbul dari berbagai sumber . Tanah merupakan sumber daya alam dengan alam tetap, menjadi kebutuhan manusia akan lahan terus meningkat . Dalam kegiatan ini akan dilakukan studi literatur tentang karakteristik perkebunan tebu, juga melakukan studi tentang agrigeofisika . perkebunan Asessmen yang telah dipelajari memiliki potensi untuk melakukan pemnafaatn saluran waduk. Kegunaan penelitian ini atau lokasi ini untuk potensi penyimpanan cadangan air sebagai perkebunan tebu proses irigasi
\end{abstract}

Kata Kunci: Agrigeofisika, self potential, irigasi, Perkebunan Tebu

\section{PENDAHULUAN}

Swasembada gula total dicanangkan oleh pemerintah Indonesia sebagai bagian dalam Road map swasembada gula (Direktorat Jenderal Gula,2012). Komoditas gula dalam perekonomomian Indonesia merupakan salah satu komoditas strategis salah satunya pada sisi produksi gula, dengan mengambil contoh luas areal tebu 452 ribu hektar ha maka produksi tebu akan tercapai sekitar 33,7 juta ton $(=2,7$ juta ton gula), kondisi ini melibatkan kurang lebih sekitar 900 ribu petani. Konsumsi gula pada masyarakat tidak kurang dari 5 juta ton setiap tahunnya, dengan peruntukan pada kebutuhan konsumsi rumah tangga maupun kebutuhan bagi bahan baku industri. makanan dan minuman (Kemendag, 2010).

Target pencapaian swasembada gula menurut sekretariat Dewan Gula Indonesia pada tahun 2014 jumlah produksi gula tebu nasional mengalami defisit 2,25 juta ton, sedangkan konsumsi gula nasional mencapai 5,7 juta ton, hal tersebut mencerminkan bahwa target yang dicanangkan oleh pemerintah pada tahun 2014 belum dapat optimal (Direktorat Jenderal Perkebunan, 2014). Masih jauhnya peluang pencapaian swasembada gula nasional disebabkan persoalan-persoalan di tingkat hulu (usahatani) dalam hal peningkatan produksi dan rendemen tebu. Sistem budidaya untuk peningkatan produksi dan rendemen tebu melalui pengolahan tanah, pemupukan dan penggunaan varietas baru telah mencapai usaha yang maksimum dan telah terjadi stagnasi sistem budidaya (Irianto et al, 2005). Alternatif upaya peningkatan produksi dan rendemen tebu selanjutnya dengan mengarahkan pada kualitas produksi tebu (rendemen/ton sugar dan produksi/ton cane), upaya ini memerlukan beberapa pola budidaya, diantaranya (1) penentuan saat dan masa tana berdasarkan kondisi iklim dan tanah, (2) perancangan irigasi suplementer (supplementary irrigation) melalaui penyediaan air tanah (aquifer) berdasarkan keberadaan bawah permukaan lahan, dalam hal ini penggunaan channel reservoir, dan (3) peningkatan kualitas tanah dengan menggunakan bahsan dasar pemupukan yang disesuaikan dengan kondisi tanah lahan (Rejekiningrum et al, 2007). Menurut Gatot (2013) bahwa adanya korelasi linier antara kecukupan air bawah permukaan pada lahan perkebunan tebu dengan hasil rendemen tebu.

Karakteristik tanaman tebu sangat unik dikarenakan tanaman ini tidak menyukai lahan 
sebagai media tanam yang terlalu basah maupun lahan yang terlalu kering (Gatot,2013). Oleh karena itu sangat dimunginkan untuk dilakukan pengelolaan sistim irigasi yang tepat. Sistem irigasi yang konvensional yang mengandalkan laju aliran permukaan (runoff velocity) sudah tidak memungkinkan menjadi penopang utama dalam kecukupan air bagi tanaman tebu. Salah satu alternatif irigasi adalah melalui sistem irigasi suplementer dengan merancang sistem channel reservoir. Keberadaan channel reservoir memanfaatkan karakteristik bawah permukaan lahan tanaman tebu sebagai upaya menanam air (water harvesting) sehingga pada saat musim penghujan air dapat disimpan dalam bawah permukaan tanah yang selanjutnya dapat didistribusikan pada saat musim kemarau maka dengan kata lain sebgai penyedia air tanah baik secara temporal maupun spatial. Selain itu, penerapan lebih lanjut adalah dapat menekan laju aliran permukaan (runoff velocity), erosi (erosion), dan pencucian hara (nutrient leaching).

Landasan dasar untuk perancangan sistem channel reversoir agar dapat dimanfaatkan secara optimal adalah melakukan pengamatan secara komprehensif karakteristik potensi struktur bawah permukaan lahan tanaman tebu. Oleh karena itu, dalam penelitian yang akan dilakukan adalah assesmen atau pengevaluasian atau pendugaan bawah permukaan lahan perkebunan tebu dengan menggunakan salah satu pengukuran dengan metode dalam agrogeofisika, yaitu metode self potential (atau spontaneous potential, SP). Pengukuran metode SP merupakan metode pasif dan paling awal digunakan dalam aplikasi eksplorasi geofisika. Secara mendasar metode ini diperuntukan untuk eksplorasi jebakan-jebakan struktur dangkal bawah permukaan yang meliputi keberadaan lingkungan bawah permukaan, hirogeologi dan aplikasi geothermal
(Kirsch,2009). Metode pengukuran SP merupakan mendiskripsikan arus searah listrik secara alami yang berasal dari anomalianomali di bawah permukaan bumi berdasarkan variasi electrochemical, electrophysical, dan proses bioelectrical, perbedaan dalam potensial-potensial bawah permukaan diantara dua titik pengukuran akan memunculkan nilai-nilai potensial dari kurang dari milivolt $(\mathrm{mV})$ hingga mencapai 1 volt dan memunculkan tanda (positif dan negatif) dari potensial yang merupakan hal penting sebagai faktor diagnosa untuk mengintepretasi anomali SP (Reynold, 1997). Oleh karena itu, assesmen bawah permukaan berbasis agrogeofisika menggunakan metode self potenstial diharapkan mampu untuk memberikan informasi secara komprehensif tentang strukutr bawah permukaan pada lahan perkebunan tebu sehingga dapat dimanfaatkan untuk perancangan channel reservoir.

Penelitian ini mengambil lokasi pada lahan perkebunan tebu di wilayah administrasi Kabupaten Jember. Pemilihan lokasi ini didasarkan pada permasalahan wilayah yang berkenaan dengan peningkatan produksi dan rendemen hasil produksi serta berkesesuaian dengan pola konservasi irigasi yang didasari pada lahan dengan curah hujan dibawah 2.000 $\mathrm{mm} / \mathrm{tahun}$, (Hidayat et al, 2012). Lokasi penelitian yang menjadi pilihan merupakan lokasi dengan iklim tropis dan curah hujan sekitar $0-1.500 \mathrm{~mm} / \mathrm{tahun}$, yaitu di wilayah kecamatan Semboro dan Umbulsari dengan angka temperatur berkisar pada $28^{\circ} \mathrm{C}-33^{\circ} \mathrm{C}$ (PEMKAB Jember, 2015). Berdasarkan informasi tersebut bahwa lokasi penelitian merupakan lokasi yang memenuhi syarat untuk dilakukan konservasi irigasi air tanah dalam pemanfaatan channel reservoir di lahan perkebunan tebu. Beberapa lokasi yang akan diteliti dapat diamati pada gambar 1 dibawah ini

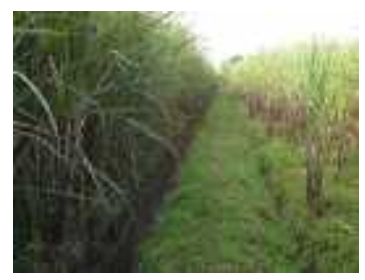

Gambar 1. Lokasi Penelitian Lahan Perkebunan Tebu 

Oleh karena itu, penelitian ini merupakan penelitian yang menghasilkan informasi awal tentang struktur bawah permukaan berdasarkan distribusi nilai potensial lahan perkebunan tebu dan dimanfaatkan untuk perancangan channel reservoir.Tujuan penelitian ini adalah mendapatkan distribusi pola nilai-nilai beda potensial struktur bawah permukaan lahan perkebunan berbasis agrogeofisika metode self potential sehingga dapat memberikan informasi untuk pemanfaatan perancangan channel reservoirPerumusan permasalahan dalam penelitian ini adalah bagaimana melakukan assesmen bawah permukaan berbasiskan agrogeofisika metode self potential (SP) yang hasilnya dapat menjadi rekomendasi teknis untuk pemanfaatan perancangan ataupun pembangunan channel reservoir sebagai upaya konservasi irigasi air pada lahan perkebunan tebu. Lingkup penelitian ini merupakan penelitian awal atau initial research untuk melakukan penelitian selanjutnya berkenaaan dengan perancangan channel reservoir bawah permukaan lahan perkebunan tebu. Oleh karenanya penelitian ini dibatasi pada lahan perkebunan tebu yang memiliki kecukupan air tanah yang minimal dan dilakukan pada daerah yang memilki karakteristik yang seragam secara agroklimatnya.

Agrigeofisika merupakan cabang ilmu geofisika yang berhubungan dengan ilmu pertanian. Geofisika merupakan ilmu yang mempelajari aplikasi prinsip-prinsip fisika untuk mempelajari bawah permukaan Bumi, baik dalam skala dangkal (dari kerak ke mantel) atau dalam skala dalam (hingga pada inti bumi). Hal-hal yang dipelajari meliputi beberapa displin keilmuan diantaranya hidrologi, meteorologi, fisika kelautan, seismologi, fisika tektonik (Telford, 1990). Secara spesifik, geofisika adalah mengaplikasikan teknik pengukuran kuantitas fisis yang bertujuan untuk mendapatkan gambaran informasi atau kondisi bawah permukaan Bumi. Oleh karena itu, teknik pengukuran bawah permukaan Bumi dalam geofisika dikembangkan dalam beberapa metode-metode eksplorasi yang memanfaatkan dan mengaplikasikan fenomena fisika, antara lain metode resistivitas, metode induksi elektromagnetik, metode ground-penetratingradar, metode magnetometri, metode selfpotential, metode seismik, metode gaya berat, metode radioaktivitas, metode resonansi magnetik nuklir, metode polarisasi induksi, dan sebagainya (Reynolds, 1997).

Self Potential merupakan potensial listrik alami yang berada di dalam bumi yang timbul dari beberapa sumber. Salah satunya bisa berasal dari potensial mineralisasi (fluids matter) yang dihasilkan dari sel elektrokimia yang dibentuk dari deposit mineral konduktif yang berhubungan dengan water table (Nyquistet al., 2002). Proses elektrokimia yang terjadi ini dapat menimbulkan potensial liquidjunction, potensial shale (Nerts potential) dan potensial mineralisasi. Penyebab lainnya adalah proses mekanik yang akan menghasilkan komponen elektrokinetis. Dengan adanya sifat-sifat atau karakteristik tersebut maka metode SP dapat digunakan untuk melokalisir daerah jebakan mineral logam.

Prinsip dasar metode SP adalah pengukuran potensial diri yang dilakukan pada sejumlah titik tertentu di permukaan tanah. Yang diukur dalam metode ini adalah beda potensial relatif dengan anggapan bahwa di titik jauh tak hingga sama dengan nol (Nyquist, 2002). Metode SP sendiri merupakan metode pengukuran listrik alam di permukaan bumi. Potensial listrik si permukaan tanah diukur dengan menggunakan voltmeter dan kontak antar voltmeter dengan tanah menggunakan suatu elektroda non polar (non-polarizing elektrodes). Tujuan dari survey SP ini adalah untuk mengetahui lebih jauh mengenai adanya batuan atau mineral yang akan menghasilkan anomali.

Ditinjau dari sebuah bola berdiameter $2 \mathrm{R}$ terpolarisasi vertikal oleh muatan $+\mathrm{e}$ dan $-\mathrm{e}$ yang terpendam dalam permukaan tanah. Diasumsikan bahwa distribusi medan listrik sama dengan polarisasi vertikal dan $\mathrm{V}$ adalah beda potensial masing-masing kutub muatan (+e dan -e). Maka beda potensial di titik p adalah: 


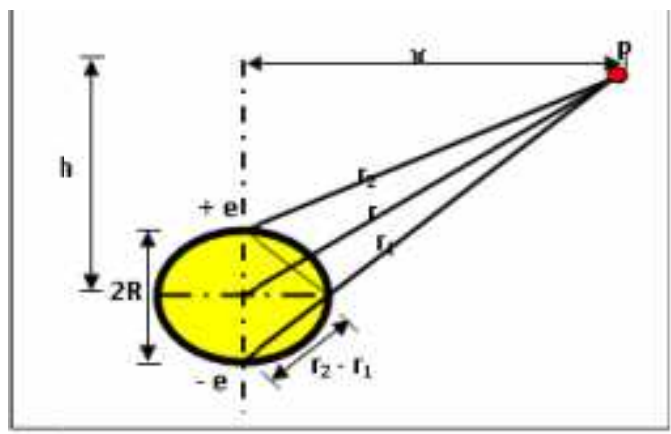

Gambar.2. Pemodelan Potensial pada titik $P$ oleh benda terpolarisasi vertikal (Telford, 1990)

$$
V_{p}=K \frac{z}{\left(x^{2}+z^{2}\right)^{3 / 2}}
$$

Persamaan (2.1) adalah persamaan potensial untuk model bola terpolarisasi vertikal. Dalam eksplorasi anomali potensial diri kemiringan benda sumber anomali diasumsikan berasosiasi dengan sudut polarisasinya. Bila polarisasi yang terjadi membentuk sudut $\alpha$. Potensial pada titik $p$ adalah $K \sin \alpha$ dan $K \cos \alpha$. Potensial pada titik $p$ adalah jumlah dari kedua potensial yang disebabkan oleh masing-masing elemen dipol yaitu:

$V_{p}=V_{1}+V_{2}=K \frac{(x \cos \alpha+z \sin \alpha)}{\left(x^{2}+z^{2}\right)^{q}}$

Anomali potensial diri dapat dihasilkan dari beberapa struktur geologi yang terpolarisasi sederhana yang diwakili oleh fungsi kontinue (Larisa, 2003):

$V_{(x, y, \theta, q)}=K \frac{(x \cos \alpha+z \sin \alpha)}{\left(x^{2}+z^{2}\right)^{q}}$

Persamaan (2.3) diatas dirubah melalui deret Taylor menjadi,

$V=V_{0}+\frac{\partial V}{\partial k} \partial k+\frac{\partial V}{\partial \theta} \partial \theta+\frac{\partial V}{\partial q} \partial h$

Sehingga persamaan tersebut menjadi suatu alat bantu yang digunakan untuk interpretasi secara kuantitatif atas data potensial yang berupa grafik atau kurva.alat bantu tersebut diturunkan secara geometris dari persamaan model tertentu. Sehingga diperoleh secara elekrokinetik maka diformulasikan sebagai berikut :

$$
V=\frac{\varepsilon}{4 \pi}
$$

$\varepsilon$ merupakan dielektrika, $\rho$ merupakan resistivitas, $\eta$ merupakan viskositas dan $\delta P$ merupakan beda tekanan dan $\mathrm{C}$ merupakan koefisien elektrofilterisasi.

Lahan merupakan sumber daya alam dengan sifat tetap, sedang kebutuhan manusia akan lahan terus meningkat. Lahan adalah suatu lingkungan fisik yang meliputi tanah, relief, hidrologi, dan vegetasi dimana faktorfaktor tersebut mempengaruhi penggunaannya (Gatot, 2013). Unsur-unsur lahan meliputi air, lereng, tanah yang merupakan faktor utama untuk kegiatan manusia. Tanah merupakan salah satu bagian dari sumber daya lahan yang mempunyai pengaruh langsung dan terus menerus bagi penggunaan pertanian. Tanah sebagai alat produksi harus dimanfaatkan sebaik-baiknya agar memperoleh hasil yang sebesar-besarnya (Hidayat et al, 2012). Untuk memanfaatkan lahan diperlukan kerja evaluasi sumber daya lahan. Evaluasi sumber daya lahan merupakan kegiatan pokok dalam rangka suatu perencanaan wilayah. Evaluasi sumber daya lahan mendasarkan pada kondisi fisik geografik merupakan masukan dasar dalam proses evaluasi lahan secara keseluruhan. Kondisi geografi yang penting dalam evaluasi sumber daya lahan adalah lereng, tanah, litologi, morfologi, penutup lahan, dan hidrologi.

Konservasi air secara prinsip merupakan penyediaan air yang berada di tanah dan dipergunakan secara efektif dan efisein dengan pola pengaturan aliran yang tepat, sehingga tidak akan terjadi kelebihan dan kekurangan penyediaan air tanah bagi lahan (Arsyad, 2000). Konservasi air pada lahan meliputi (a) peningkatan pemanfaatan komponen hidrologi baik pada air permukaan (runoff velocity) maupun padan air tanah (groundwater) dan (b) terjadi efiseiensi penggunaan dan pemakaian air irigasi. 
Pengelolaan air pemukaan yang banyak dikenal dengan manajemen air permukaan (surface water management) diantaranya meliputi (1) penegndalaian aliran permukaan; (2) pemanenen air (water harvesting) (3) peningkatan infiltrisasi tanah; (4) pengelolaan tanah; (5) Penggunaan untuk bahan penyumbat tanah. Sedangkan, pada pengeloaan aliran bawah permukaan yang dikenal dengan manajemen air bawah permukaan (sub-surface water management) dapat dilakukan dengan (1) perbaikan drainase; (2) penegmdalaian perkolasi (deep percolation) dan aliran bawah permukaan dan (3) perubahan struktur tanah lapiasan bawah permukaan. Kegiatan ini akan memungkinkan untuk meningkatkan efiseinsi pemakaian air tanah karenan akibat hilangnya air yang berlebih dan memberikan ruang bagi akar tanaman untuk berkembang lebih luas dalam lapisan tanah, sehingga akan mengurangi kekeringan pada lapisan permukaan (Gambar 2.3). Oleh karena itu kegiatan assesmen bawah permukaan berbasis agrogeofisika sangat disarankan (Barry,2008).

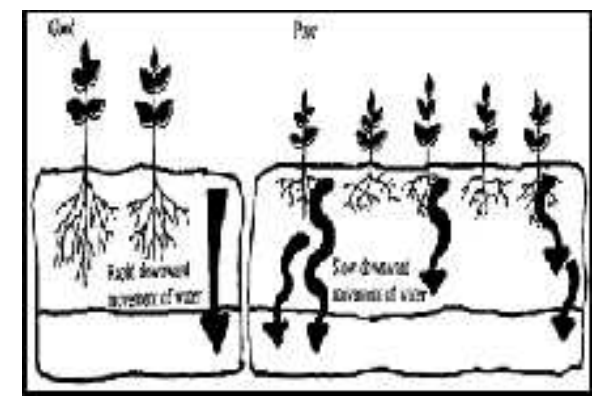

Gambar.3. Profil Perakaran pada bawah permukaan lahan (Barry, 2008)

\section{METODE PENELITIAN}

Kegiatan penelitian skim pembinaan ini akan dilaksanakan pada lahan perkebunan tebu di wilayah kabupaten Jember. Kabupaten Jember terletak pada posisi $8^{0} 12^{\prime} 00^{\prime \prime}$ sampai $8^{0} 12^{\prime} 30^{\prime \prime}$ Lintang Selatan dan $113^{0} 26^{\prime} 00^{\prime \prime}$ sampai $113^{0} 27^{\prime} 00^{\prime \prime}$ Bujur Timur. Objek penelitian merupakan lahan perkebunan budidaya tanaman tebu, sehingga lokasi penelitian dan barang penelitian untuk pengambilan sample tanah akan berkisar di area lahan perkebunan tebu di wilayah kabupaten Jember.

Adapun tahapan penelitian dengan judul : "Agrogeofisika Assesmen Bawah Permukaan Pada Lahan Perkebunan Tebu Untuk Pemanfaatan Channel Reservoir Dengan Metode Self-Potential" meliputi :

a. Tahap Persiapan

Pada kegiatan ini akan dilakukan studi literatur mengenai karakteristik dari lahan perkebunan tebu, selain itu juga melakukan studi mengenai agrogeofisika.

b. Survey Geologi Lahan

Survei geologi meliputi bentuk tanah lahan; lahan basah (wet land) dan lahan erring (dry land), faktor hidrogeologi lahan dan kondisi geologi serta potensi lahan.

c. Penyiapan Bahan dan Alat pengukuran

Bahan-bahan yang dipergunakan dan pemyiapan alat-alat ukur (Voltmeter) serta alat pendukung seperti kabel, elektroda dan converter harus dalam keadaan yang baik.

d. Kalibrasi Alat Pengukuran metode SelfPotential

Kegiatan menyakinkan bahwa alat ukur dapat berkerja dengan baik dan sempurna, dengan mekanisme mengukur porous pot dengan interval 2 meter dan mendapatkan niai potensial dibawah $2 \mathrm{mV}$

e. Penentuan Jejaring Lintasan Akusisi

Tahapan kegiatan ini dilaksanakan untuk membuat pola jejaring lintasan akusisi yang sesuai dengan tujuan dan permsalahan penelitian.

f. Akusisi Data Penelitian

Tahapan pengambilan data dinamakan yahapan akusisi data penelitian. Akusisi data metode SP menggunakan teknik pengambilan data dengan konfigurasi metode gradien (gradient method or leap frog). 


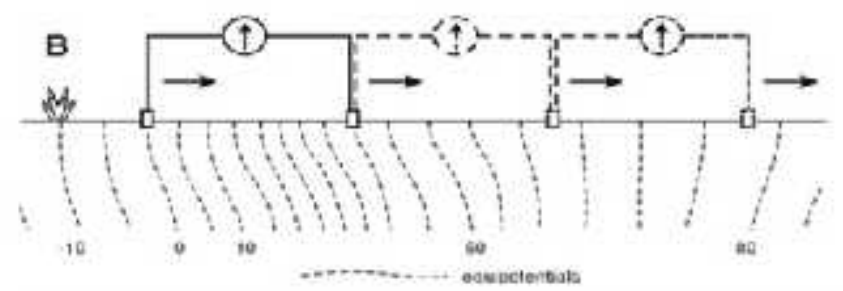

Gambar 4. Metode Akusisi SP; Metode Gradien (Kirsch,2009)

g. Asessmen hasil data Penelitian

Tahapan assesmen hasil penelitian merupakan tahapan yang meliputi pengolahan data menggunakan bahasa pemrograman dan pengolah data selfpotential dan kemudian dilakukan penganalisaan data untuk memperoleh intepretasi data yang benar dan sesuai. Tahapan ini dilakukan seturut dengan pengolahan hasil grafik data potensial untuk data sintetik dan menggambarrkan distribusi potensial pada kedalaman tertentu sesuai dengan nilai resitivitasnya, hasil delineasi penggambaran data potensial menurut kedalaman diperkuat dengan penyebaran distribusi potensial pada data sintetik. Pola grafik data potensial bekesesuaian dengan pola penjalaran nilai potensial untuk monitoring lubang pengeboran sumber air (Reynold, 1997) dan sebagaimana nampak sebagai berikut :

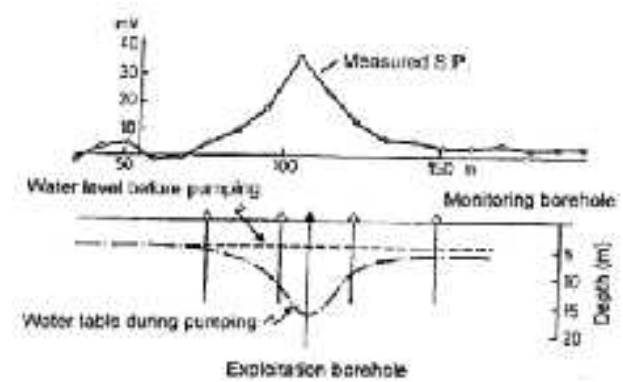

Gambar 5. Kesesuaian grafik nilai potensial dengan kedalaman (Reynold, 1997)

Oleh karena itu, guna mengasessment data hasil penelitian dari hasil-hasil akuisisi maka dapat dirancang pengolahan dengan menggunakan data sintetik yang seturut dan berasosiasi dengan penggambaran seperti pada gambar 6. Hasil pengolahan data sintetik menujukkan sebagai berikut :

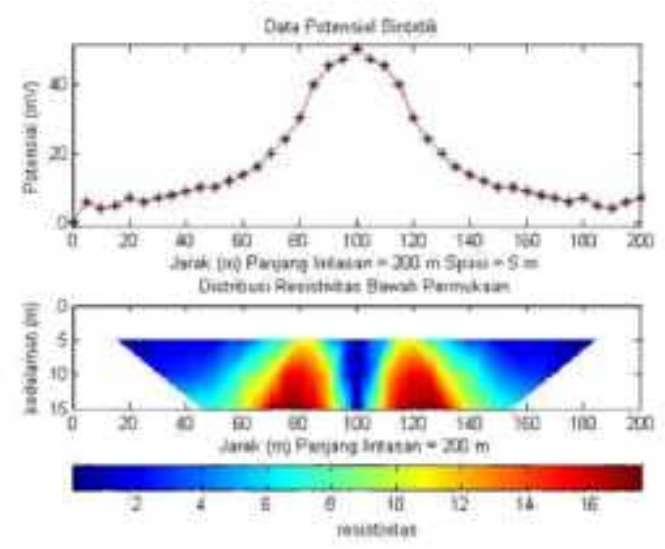

Gambar 6. Kesesuaian grafik nilai potensial sintetik dengan resistivitas 
Pengintepresian gambar 6 untuk memberikan kejelasan tetntang deliniasi bawah permukaan berdasarkan nilai potensialnya. Pada grafik menunjukkan bahwa semakin terdapat nilai potensial yang tinggi dan memiliki perbebedaan signifikan dari data potensial sekitarnya maka daerah tersebut merupakan daerah jebakan fluida, hal ini sesuai dengan penggambaran di gambar 4.10, selain itu hasil delineasi juga ditampakkan pada kontras warna pada distribusi potensial yang menujukkan bahwa adanya kontras yang sangat tajam antara besaran resistivitas dan menampilkan kedalaman. Seperti pada persamaan (2.5) menyatakan nilai potensial berbanding lurus dengan resistivitasnya, sedangakan nilai resistivitas berbanding terbalik dengan konduktivitasnya, maka dari penggambaran di atas nampak bahwa semakin tinggi nilai resistivitas maka nilai konduktivitasnya semakin kecil maka ditampilkan dengan kontras warna merah yang mengindikasikan sebagai batuan yang padat tanpa adanya fluida sedangkan semakin kecil nilai resisitivitasnya maka nilai konduktivitasnya semakin besar, hal ini dapat dianalogikan bahwa pada daerah tersebut merupakan jebakan fluida atau batuan dengan dominasi fluida. Kondisi bawah permukaan yang ditampilkan pada pencitraan distribusi potensial bawah permukaan dapat dijelaskan dan ditekankan pada distribusi pemetaan anomaly dengan data sintetik sebagaiamana dapat dilihat berikut ini :

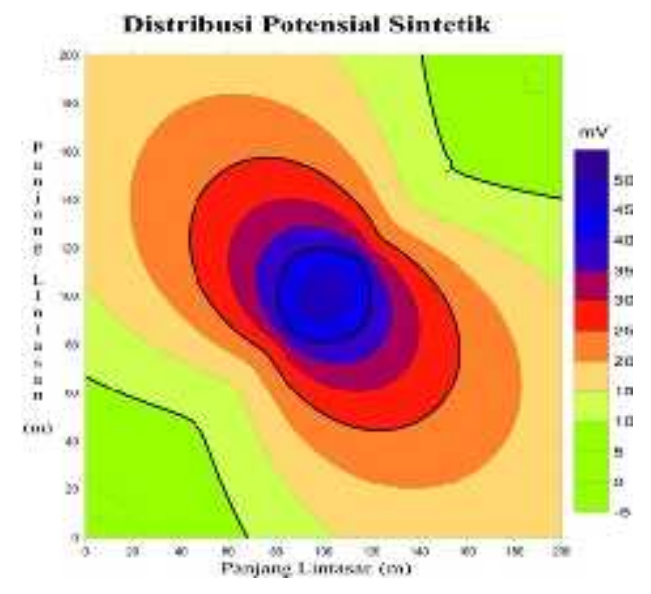

Gambar 7. Pemetaan distribusi potensial sintetik

\section{HASIL DAN PEMBAHASAN}

Penelitian agrogeofisika untuk lahan perkebunan tebu beberapa lokasi di kaburpaten jember telah dilaksaksanakan. Lahan perkebunan tebu yang menjadi target dalam penelitian menggunakan metode self potential merupakan lahan perkebunan tebu yang memiliki sifat tanah secara geologi dikenal dengan lahan kering dan lahan basah. Pada penelitian ini indentifikasi lahan perkebunan tebu dengan kategori lahan basah (wet land) dan lahan kering (dry land) menggunakan baik data sekunder, yaitu data curah hujan pada daerah penelitian maupun menggunakan data primer yaitu menggunakan data evaluasi derajat keasaman tanah dengan menggunakan pH meter khusus untuk tanah. Sehingga hasil menunjukkan bahwa untuk lahan basah (wet land) memiliki curah hujan rata-rata $1.000-$ $1.500 \mathrm{~mm} /$ tahun dengan nilai $\mathrm{pH}$ tanah berada pada kisaran 3.0-4.0 sedangkan pada lahan kering (dry land) yang memiliki curah hujan rata-rata $500-1.000 \mathrm{~mm} /$ tahun dengan nilai pH tanah pada kisaran di atas 7.0.

Hasil akusisi data penelitian pada lahan perkebunan tebu untuk lahan basah (wet land) yang terletak di desa Semboro Kabupaten Jember, memberikan hasil grafik data potensial observasi yang diasosiasikan dengan hasil invers distribusi resistivitas pada bawah permukaan seturut dengan kedalamannya sehingga dapat ditampilkan sebagaimana berikut : 

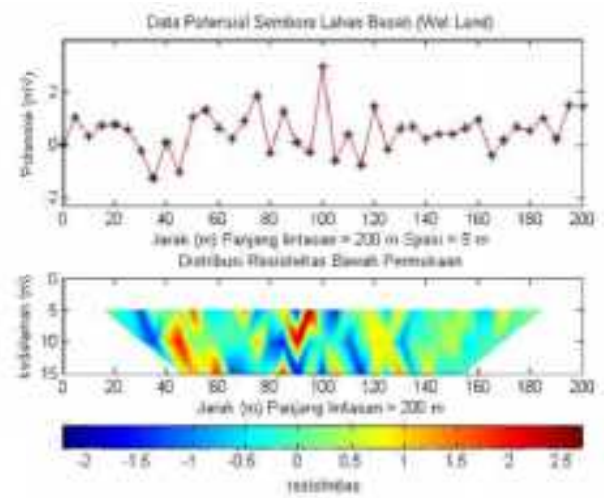

Gambar 8. Hasil distribusi data potensial dan distribusi resistivitas pada lahan basah (wet land)

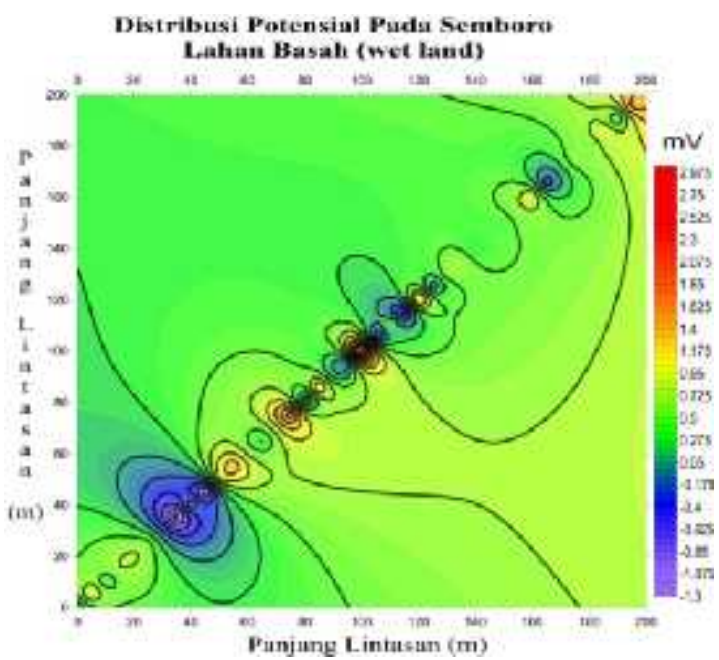

Gambar 9. Hasil pemetaan distribusi data potensial observasi pada lahan basah (wet land)

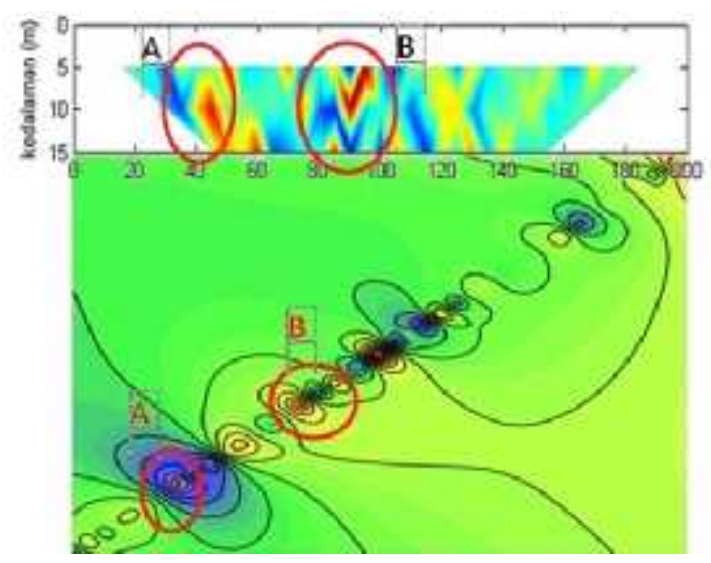

Gambar 10. Hasil titik perancangan channel reservoir di Semboro pada lahan basah (wet land)

Hasil akusisi data penelitian pada lahan yang selanjutnya adalah pada lahan dengan kategori lahan kering (dry land). Lahan perkebunan tebu ini terletak di desa Umbulsari kabupaten Jember. Dari hasil pengolahan data potensial observasi hasil akusisi penelitian diperoleh grafik yang selanjutnya juga dilakukan proses inversi untuk memberikan informasi distribusi resistivitas pada daerah yang menjadi target. Hasil pola grafik data potensial observasi yang selaras dengan 
distribusi reistivitas dapat ditampakkan sebagai berikut:

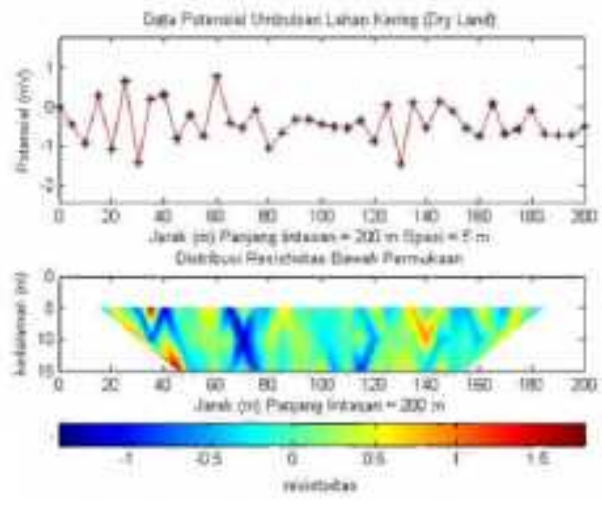

Gambar 11. Hasil distribusi data potensial dan distribusi resistivitas pada lahan kering (dry land)

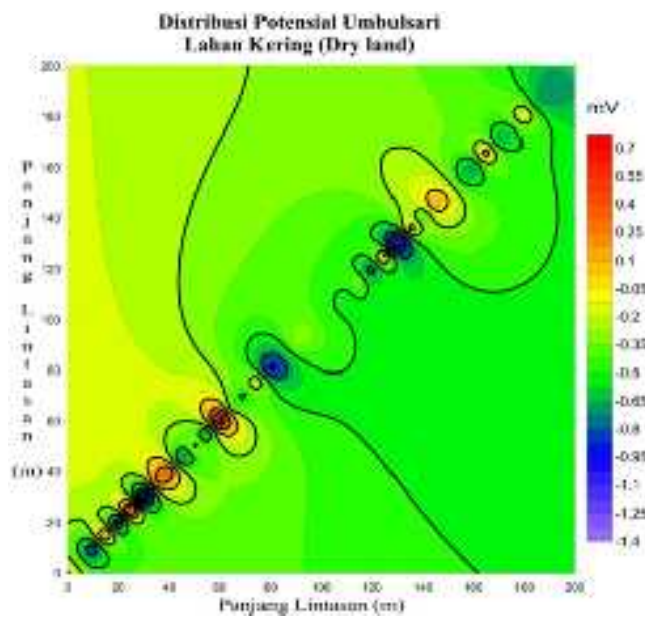

Gambar 12. Hasil pemetaan distribusi data potensial observasi pada lahan kering (dry land)

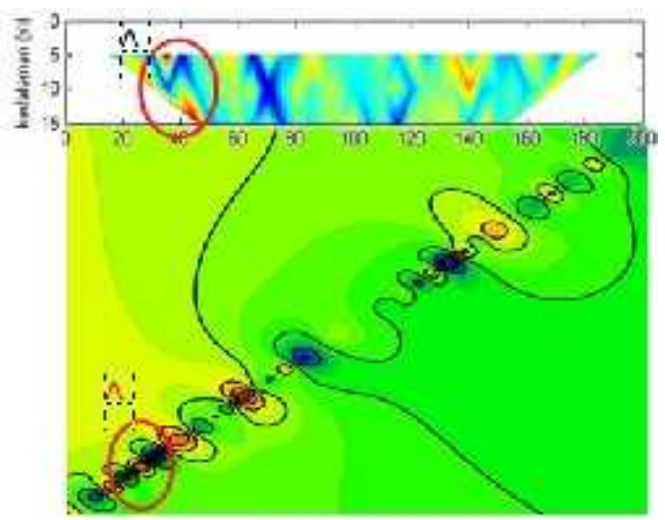

Gambar 13. Hasil titik perancangan channel reservoir di Umbulsari pada lahan kering (dry land)

Hasil penelitian pada lahan perkebunan tebu menggunakan metode agrogeofisika self potential telah dapat diklasifikasikan dalam pembahasan mengenai lahan perkebunan tebu dengan kategori lahan basah di desa Semboro dan lahan perkebunan tebu dengan kategori lahan kering di desa Umbulsari. Pembahasan memiliki rangkaian urutan dari pembahasan mengenai grafik data potensial observasi, kemudian dilanjutkan dengan pembahasan 
mengenai distribusi resistivitas berdasarkan pola pencitraan kontras warna dan diteruskan dengan mengidentifikasi hasil pemetaan data observasi. Keseluruhannya diakhir dengan mengintepretasikan hasil distribusi resisitivitas dengan hasil pemetaaan distribusi potensial untuk mencapai titik-titik efektif pemanfaatan channel reservoir pada setiap lahan perkebunan tebu beserta tingkat kedalaman dari permukaan dan tinggi jebakan fluida atau yang dikenal dengan water table.

Lahan perkebunan tebu dengan kategori lahan basah (wet land) yang terletak di desa Semboro memiliki distribusi nilai potensial yang beragam dan sangat kontras pada beberapa titik pengukuran. Nilai potensial potifif memiliki arti sebagai nilai potensial refleksi adanya anomali yang merupakan terdiri dari batuan lunak atau berada pada zona lemah, sedangkan nilai potensial yang negatif merupakan anomali yang berada pada daerah batuan keras. Keberadaan yang signifikan antara nilai potensial yang negatif dan positif secara bersisipan memberikan arti bahwa daerah tersebut merupakan daerah jabakan fluida atau yang dikenal sebagai daerah water table. Pada daerah ini kondisi yang demikian tertampil pada posisi di lintasan $20-40 \mathrm{~m}$ dan 80 - $100 \mathrm{~m}$, hal ini ditekankan pada pola kontras warna distribusi resistivitas pada gambar 8 nampak bahwa adanya kontras warna yang sesuai dengan pengolahan data sintetik pada gambar 6 , sehingga dimungkinkan pada daerah dan lokasi titik tersebut merupakan daerah yang memunginkan adanya jebakan fluida. Jebakan fluida yang tertampil pada pola kontras distribusi resisitivitas berada pada kedalaman $5-15 \mathrm{~m}$ dibawah permukaan dengan panjang jebajan fluida yang lebih dari $10 \mathrm{~m}$. Besarnya panjang jebakan fluida dapat diamati pada hasil pemetaan nilai potensial di gambar 9, nampak bahwa warna yang tertampil antara warna biru dikelilingi oleh warna merah seperti pada data sintetik di gambar 7 . Kejelasan hasil intepretasi dapat diamati secara baik dan menyeluruh serta detail pada gambar 5.6, nampak pada titik dugaan $\mathrm{A}$, memiliki karakteristik water table atau jebakan fluida di kedalaman $10-15 \mathrm{~m}$ dari atas permukaan dengan panjang jebakan fluida sekitar $8-5 \mathrm{~m}$ pada titik lokasi 40 - 50m dari titik awal pengamatan. Sedangkan untuk titik dugaan B, memiliki jebakan fluida pada kedalaman 5-10 $\mathrm{m}$ dari atas permukaan dan panjang jebakan fluida $10-15 \mathrm{~m}$ pada lokasi titik pengukuran 80 - $100 \mathrm{~m}$ dari titik awal pengukuran. Jadi dapat tarik rekomendasi bahwa kedua titik memiliki potensi yang baik untuk dimanfaatkan sebagai channel reservoir bawah permukaan. Karena baik titik dugaan A dan titik dugaan B mampu untuk menampung dan menyimpan air bawah permukaan.

Hasil yang berbeda nampak pada lahan perkebunan tebu untuk kategori lahan kering (dry land), pada grafik hasil data potensial observasi terlihat bahwa nilai potensial kecil dengan perbedaan antara potensial positf dan negatif tidak terlalu signifikan. Hal ini disebabkan bahwa keberadaan anomali bawah permukaan lahan perkebuanan tebu lebih didominasi oleh tanah yang keras dan sedikit yang memiliki jebakan fluida. Pola grafik data potensial observasi yang diperlihatkan pada gambar 11 juga diindikasikan pada pola kontras warna resistivitas bawah permukaan yang menujukkan tidak adanya warna kontras yang bersisipan. Warna biru yang muncul disebabkan karena kondisi tanha tersbut lebih lembek daripada tanah sekitarnya akan tetapi buka meruakan jebakan fluida. Akan tetapi, pada lahan ini masih terdapat jebakan fluida meskipun cuku sedikit pada lokasi sekitar 20 $30 \mathrm{~m}$ setelah titik pengukuran dan memiliki kedalaman sekitar $10-15 \mathrm{~m}$ dengan panjang kurang dari $5 \mathrm{~m}$. Kondisi ini juga dapat ditampakkan melalui gambar 12 dari pemetaan distribusi nilai potensial yang menunjukkan kecilnya jebakan fluida. Gambar 10 lebih menetapkan bahwa titik dugaan di lahan perkebunan untuk kategori lahan kering (dry land) pada titik A, yang memiliki karakteristik panjang jebakan fluida sekitar $5 \mathrm{~m}$ dengan kedalaman 11 -15m dan berada pada $20-30 \mathrm{~m}$ dari titik awal pengukuruan. Namun demikian, titik tersebut masih dapat dipergunakan untuk pemnafaaatan channel reservoir.

\section{KESIMPULAN}

Berdasarkan hasil penellitian yang telah dilakukan dapat disimpulkan bahwa assessmen bawah permukaan menggunakan metode agrogeofisika self potential pada lahan perkebunan tebu untuk pemanfaatan channel reservoir. Lahan perkebunan tebu yang dipilih merupakan lahan perkebunan tebu dengan 
kategori lahan basah (wet land) dengan ciri khas memilki curah hujan berkisar antara 1.000 - $1.500 \mathrm{~mm} /$ tahun dengan nilai $\mathrm{pH}$ tanah sebesar 3.0 - 4.0. Pada lahan perkebunan ini hasil assesmen bawah permukaan terdapat 2 (dua) titik dugaan yang dapat diguanakan sebagai pemanfaatan channel reservoir. Titik dugaan $\mathrm{A}$, memilki karakteristik water table atau jebakan fluida di kedalaman $10-15 \mathrm{~m}$ dari atas permukaan dengan panjang jebakan fluida sekitar $8-5 \mathrm{~m}$ pada titik lokasi $40-50 \mathrm{~m}$ dari titik awal pengamatan, sedangkan titik dugaan B, memiliki jebakan fluida pada kedalaman 5-10 m dari atas permukaan dan panjang jebakan fluida $10-15 \mathrm{~m}$ pada lokasi titik pengukuran $80-100 \mathrm{~m}$ dari titik awal pengukuran. Pada lahan perkebuanan tebu yang lain dipilih berdasarkan curah hujan berkisar $500-1.000 \mathrm{~mm} /$ tahun dengan nilai $\mathrm{pH}$ tanah di atas 7.0, lahan ini dikenal dengan lahan kering (dry land). Assesmen pada ;lahan perkebunan ini hanya dihasilkan 1 (satu) titik potensial untuk pemanfaatan channel reservoir dengan karakteristik panjang jebakan fluida sekitar 5m dengan kedalaman $11-15 \mathrm{~m}$ dan berada pada $20 \quad-30 \quad m$ dari titik awal pengukuruan.

Oleh karena asessmen lahan perkebunan yang telah diteliti memiliki potensi untuk dilakukan pemnafaatn channel reservoir. Kegunaan penelitian ini atau lokasi ini untuk potensi penyimpanan cadangan air sebagai proses irigasi lahan perkebunan tebu.

\section{UCAPAN TERIMA KASIH}

Penulis mengucapkan terima kasih kepada program penelitian skim pembinaan tahun anggaran 2015, sumber dana DIPA Universitas Jember.

\section{DAFTAR PUSTAKA}

Arsyad S, (2000), Konservasi Tanah dan Air, Serial Pustaka IPB Press, Bogor

Badan Penelitian Dan Pengembangan Pertanian, (2007), Prospek dan Arah Pengembangan Agribisnis Tebu, Edisi Kedua, Departemen Pertanian, Jakarta
Barry J, et al, (2008), Handbook of Agricultural Geophysics, CRC Press, London, New York.

BPS, (2013), Jawa Timur dalam Angka tahun 2013, Badan Pusat Statistik, Surabaya

Direktorat Jenderal Perkebunan, (2013), Kegiatan 2013 untuk terwujudnya Swasembada Gula 2014,Makalah Musrenbangtan, Jakarta

Direktorat Jenderal Perkebunan, (2014), Roadmap Swasembada Gula, Kementrian Pertanian Jakarta, Jakarta

Gatot Irianto, (2013), Tebu Lahan kering dan Kemandirian Gula Nasional, Majalah Sinar Tani Balai Penelitian Agroklimat dan Hidrologi, Jakarta.

Guymon G L, (1994), Unsaturated Zone Hydrology, PTR Prentice Hal, New Jersey

Hidayat, A dan Mulyani, (2012), Lahan Kering untuk Pertanian menuju pertanian produktif dan ramah lingkungan, Pusat Penelitian dan pengembangan Tanah dan Agroklimat, Bogor

Irianto, G., E. Surmaini, W. Estiningtyas, dan Kaslan.K. (2005). Teknologi Irigasi Untuk Meningkatkan Produksi dan Rendemen Tebu Lahang Kering. Laporan Akhir. Kerjasama PAATP dengan PT Gunung Madu Plantations.

Kemendag, (2010), Meredam Gejolak : Sistem Distribusi Kebutuhan Pokok di Indonesia, Badan Penelitian dan Pengembangan Perdagangan, Kemendag, Jakarta

Kirsch R, (2009), Groundwater Geophysics; A tool for Hydrogeology, second edition, Springer, Germany

Larisa Pozdnyakova,(2003), Electrical Properties od Soils, Landviser,University of Wyowing 
JPFK, Vol. 2 No. 1, Maret 2016, hal 36 - 47

http://e-journal.ikippgrimadiun.ac.id/index.php/JPFK

Nyquist JE., and Corry. C.E, (2002), Self Potential: The Ugly Duckling of Environmental, Geophysics The Leading Edge, Vol. 21. No. 5 May 2002

PEMKAB Jember, (2015), Rencana Kerja Pembangunan Daerah Kabupaten Jember Tahun 2015, Kabupaten Jember.

Rejekiningrum, Ramadani, Apriyana, dan Haryono, (2007), Identifikasi Dan Karakterisasi Potensi Air Tanah Untuk
Pengembangan Irigasi Suplementer Di Pabrik Gula Rendeng Dan Trangkil Jawa Tengah, Journal Agromet, Jakarta.

Reynolds J.M., (1997), An Introduction to Applied and Environmental Geophysics, JohnWilley \& Sons; New York

Telford, W.M., Sheris, R. E , and Gilbert, L. P, (1990), Applied Geophysics Second edition, Cambridge University, New York. 